\title{
Morphological, chemical and developmental aspects of the Dufour gland in some eusocial bees (Hymenoptera, Apidae): a review
}

\author{
Fábio Camargo Abdalla
}

Universidade Federal de São Carlos (UFSCar), Campus de Sorocaba. Avenida Darci Carvalho Dafferner, 200, 18087-125 Alto da Boa Vista,
Sorocaba-SP, Brasil. fabdalla@ power.ufscar.br

\begin{abstract}
Morphological, chemical and developmental aspects of the Dufour gland in some eusocial bees (Hymenoptera, Apidae): a review. The present revision focused on the more recent data about the Dufour gland in some eusocial bees, taking in account general aspects of its morphology, secretion chemical nature, bio-synthetic pathway and development. Many functions have been attributed to this gland in eusocial bees, but none are convincing. With the new data about this gland, not only the secretion chemical pathway of the Dufour gland may be reasonable understood, as its function in some eusocial bees, especially Apis mellifera Linné, 1758, which has been extensively studied in the last years.
\end{abstract}

KEYWORDS. Exocrine glands; meliponines; pheromone.

\begin{abstract}
RESUMO. Aspectos morfológicos, químicos e do desenvolvimento da glândula de Dufour em algumas abelhas eussociais (Hymenoptera, Apidae): revisão. Esta revisão aborda os mais recentes dados sobre a glândula de Dufour em algumas abelhas eussociais, considerando aspectos gerais da sua morfologia, do seu desenvolvimento, da natureza química da sua secreção, assim como sua via bio-sintética. Muitas funções têm-se atribuído à glândula de Dufour nas abelhas eussociais, mas nenhuma suficientemente convincente. Os novos dados a respeito dessa glândula permitem não só conhecer razoavelmente bem a via bio-sintética como a função da secreção da glândula de Dufour em algumas abelhas eussociais, especialmente em Apis mellifera Linné, 1758, a qual tem sido extensivamente estudada nos últimos anos.
\end{abstract}

PALAVRAS-CHAVE. Feromônios; glândulas exócrinas; meliponíneos.

Since the pioneer data of de Lello (1971) and Billen (1987), when they definitively disassociated the Dufour gland of bees as a sting associated gland and pointed it on as a reproductive accessory gland, much progress has been done about the knowledge of this gland in bees, especially in Apis mellifera Linné, 1758.

In A. mellifera many aspects of its morphology (Abdalla \& Cruz-Landim, 2001b,d,; 2004a), physiology, secretion cycle and chemical nature were understood (Katazav-Gozansky et al. 1997, 2000,01,03,04, Abdalla 2002; Abdalla et al. 2001; Abdalla \& Cruz-Landim 2004a; Martin \& Jones 2004) and now this background has been driving the studies of the gland in other species and groups of eusocial bees, as in the neotropical stingless bees or meliponines (Cruz-López et al. 2001; Abdalla \& Cruz-Landim 2002, 2004b, 2005; Patricio et al. 2003:04; Abdalla et al. 2004).

To visualize the progress of the Dufour gland functional and physiological knowledge in A. mellifera we need to focus on some important subjects: 1 . The Dufour gland secretion and morphology caste-specificity, 2. The gland morphology and the secretion pathway plasticity, 3 . The gland chemical pathway control and its relationship with the evolutionary approach to enhance the sociability.

\section{METHODS CONCERNMENTTOTHEAUTHOR'S RESULTS}

Transmission electron microscopy, routine: The glands were fixed in $2 \%$ glutaraldehyde and $4 \%$ paraforalmaldehyade in $0.2 \mathrm{M}$ sodium cacodilate buffer at $\mathrm{pH} 7.2$ for, at least, $2 \mathrm{hr}$.
After fixation, the glands were washed twice in $0.2 \mathrm{M}$ sodium cacodilate buffer, post-fixed in $1 \%$ osmium tetroxide in the same buffer and stained with $2 \%$ uranyl acetate in $10 \%$ ethanol during $2 \mathrm{~h}$, being dehydrated in a series of acetone $(30-100 \%)$. The glands were embedded in resin Epon Leica, following the usual procedures. Thin sections were cut with a diamond knife, stained with lead citrate, and examined under electron microscope Philips.

Transmission electron microscopy, zinc iodide - osmium tetroxide (ZIO) - (Reinecke \& Walter 1978): the glands were fixed in $2 \%$ glutaraldehyde, $4 \%$ paraformaldehyde in $0.1 \mathrm{M}$ sodium cacodilate buffer, $\mathrm{pH} 7.4$, for, at least, $2 \mathrm{~h}$ at room temperature. The glands were then rinsed twice in the same buffer plus $8 \%$ sucrose, and subsequently rinsed four times in $0.01 \mathrm{M}$ Tris, $\mathrm{pH} 7.4$, containing $1.13 \mathrm{M} \mathrm{NaCl}, 0.01 \mathrm{M} \mathrm{CaCl}_{2}$ and $0.03 \mathrm{M} \mathrm{MgCl}_{2}$. The fixed glands were incubated in the dark for 17 to $22 \mathrm{~h}$, at $4{ }^{\circ} \mathrm{C}$, in zinc iodide - osmium tetroxide reagent prepared as follow: $3 \mathrm{~g}$ zinc powder and $1 \mathrm{~g}$ resublimed iodide. The two substances were mixed with the Tris buffer in a 1:1 ratio. Four parts of this solution were mixed with one part of $2 \% \mathrm{OsO}_{4}$ solution in distilled water for $5-10 \mathrm{~min}$ before use. After incubation, the glands were rinsed once in Tris buffer and twice in $0.1 \mathrm{M}$ phosphate buffer, dehydrated in ethanol, and embedded in resin Epon Leica. The sections without further contrast were observed in a transmission electron microscope Phillips.

Transmission electron microscopy, lanthanum nitrate impregnation - (Lane et al. 1986): to a solution of 2\% nitrate lanthanum $\mathrm{pH} 4.0$ was added the same volume of $2 \mathrm{M}$ cacodilate 
buffer $\mathrm{pH}$ 6.8. The mixture was used to prepare the $2.5 \%$ glutaraldehyde fixative. The glands were left in the fixative for $24 \mathrm{~h}$ at room temperature. The material was then rinsed in the same buffer and prepared for routine transmission electron microscopy without post-fixation. The sections without further contrast were observed in a transmission electron microscope Phillips.

Gas chromatography and mass spectrometry analysis (Morgan \& Wadhans 1972): The glands were analyzed directly in a Hewlett-Packard series 5890A gas chromatograph coupled to a selective mass detector HP series 5970B (quadrupole spectrometer) operated at $70 \mathrm{eV}$ of electric impact ionization. The system was controlled and the data were stored on a Hewlett-Packard series 300 microcomputer connected to a HP 5971/5972 MSD Chemstation (Chemical Ecology Group, Department of Chemistry, Keele University, United Kingdom). The analyses were done using a $30 \mathrm{~m}$ fused silica column Rtx$5(30 \mathrm{mx} 0.37 \mathrm{mx} 0.5 \mathrm{im})$ covered with poly $(5 \%$ biphenyl-95\% dimethyl) siloxane.

The oven was programmed to reach a final temperature of $325^{\circ} \mathrm{C}$, starting from a initial temperature of $60^{\circ} \mathrm{C}$ and rising at a rate of $10^{\circ} \mathrm{C} \mathrm{min}{ }^{-1}$. Helium was used as the carrier gas at a flow rate of $1 \mathrm{~mL} \mathrm{~min}^{-1}$. Injections of extracts of Dufour gland were made in splitlees mode with a purge off time of $0.75 \mathrm{~min}$ and a solvent delay of $5 \mathrm{~min}$ before the mass spectrometer was switched on. The mass detector was programmed to detect a minimum mass of $35 \mathrm{Da}$ and a maximum mass of $550 \mathrm{Da}$.

\section{MORPHOLOGICAL, CHEMICALAND DEVELOPMENTAL ASPECTS OF THE DUFOUR GLAND IN SOME EUSOCIAL BEES: ENPHASIS ON Apis mellifera Linné, 1758.}

\section{The Dufour gland secretion and morphology caste-} specificity. In A. mellifera we know that the queen may have not the exclusivity of male production, since some workers may develop their ovaries and lay haploid eggs (Visscher 1996; Patrício \& Cruz-Landim 2003), which, as those of the queen, will raise males by parthenogenesis. However, the worker's eggs are eliminated by nestmate workers (Ratnieks 1995), because for workers it is genetically more advantageous take care of the queen' sons than their nephews, which are genetically nearer from them (Hamilton 1964). Ratnieks (1995) noticed that the workers are able to recognize the two kinds of eggs, from egg-layer workers and queen, and supposed that the best candidate for egg marking would be the Dufour gland secretion, since this gland opens into the dorsal vaginal wall and is surrounded by muscle fibers that suggests a certain control of the secretion discharging by muscle contraction and consequent gland collapse and secretion spraying (Billen 1987; Abdalla \& Cruz-Landim 2001b). Ratnieks' hypothesis was that the queen's Dufour gland would mark the passing eggs during the queen oviposition, marking and distinguishing them from the egg's workers by the nestmate workers, as called for him "policing workers".

Katazav-Gozansky et al. (1997) demonstrated that in A. mellifera there is a caste-specificity between the queen and worker gland secretion. In queens the Dufour gland secretion is composed of hydrocarbons and esters, whereas in workers only of odd long chair hydrocarbons similar to those of the queen. This secretion caste-specificity would be the key for explaining how the workers recognize between the layer workers' and queen's eggs, e.g., the queens could coat her eggs with the gland secretion during oviposition, being the esters the signal substances for policing workers identification. In addition, the egg-layer queen and worker glands are larger than the virgin queens and non-egg layer workers (Tab. I), this also occurs in other social bee species. In Bombus terrestris Linné, 1758 the egg-layer queen and workers present the largest glands (Abdalla et al. 1999a,b), suggesting that the Dufour gland in these eusocial species is straightly related with the ovarian development and consequently with reproductive functions (Tab. II).

Besides the anatomy, morphology and caste-specificity of the Dufour gland indicate that it would be the best candidate to the queen egg-marking for nestmate worker recognition, Katzav-Gozansky et al. (2001) reveled that both synthetic esters and Dufour gland extracts do not protect worker-laid eggs against oophagy by the policing workers.

Abdalla (2002) demonstrated that the relationship between worker ovary development and Dufour gland presence is not a constant in meliponines. Some meliponine worker may not have the Dufour gland, even in those species where the workers also develop the ovaries independently of the colony condition (Tab. III), but it is present in all queens independently of the species considered (Kerr \& Lello 1962). However, in the species that present the Dufour gland only in queen its importance seems greater than in other species that present in both castes, since in the first it become a cast-specific gland and may play roles in reproduction and/or in functions related with eusociability.

\section{The gland morphology and the secretion pathway plasticity.} The gland morphology and the secretion pathway plasticity may constitute tips for understanding its function in $A$. mellifera.

According to Katazav-Gozansky et al. (1997), egg-layer workers may produce some esters found in the queen Dufour gland, this in theory may elicit doubts to the Ratnieks' hypothesis of egg-marking function for the queen Dufour gland, since the egg-layer workers may mimic the queen Dufour gland (Katzav-Gozansky et al. 2001).

Morphologically, the worker Dufour gland cells are enable to synthesize esters, seeming very inactive and presenting a non-developed smooth endoplasmic reticulum (Fig. 1A). This cytoplasm aspect suggests absence of cellular machinery and enzyme secretion to produce any exporting substance (Abdalla \& Cruz-Landim 2004a). Conversely, egg-layer workers and juvenile hormone treated nurse-aged workers present intracellular features like the queen cells (Fig. 1B), very developed smooth endoplasmic reticulum, some Golgi complex and many polymorphic mitochondria randomly spread in the cytoplasm, such cellular feature indicates the lipid nature of 
Table I. Measurements of the length and diameter of the Dufour gland of Apis mellifera and statistical analysis of the data.

\begin{tabular}{lccc}
\hline Caste & Individuals $(\mathrm{N}=10)$ & Length $(\mathrm{mm}) \mathrm{Means} / \mathrm{CV}$ & Diameter $(\mathrm{Mm}) \mathrm{Means} / \mathrm{CV}$ \\
\hline \multirow{2}{*}{ Workers } & Newly-emerged & $0.83 / 0.002 \mathrm{~A}$ & $0.17 / 0.001 \mathrm{~A}$ \\
& Nurse & $0.83 / 0.001 \mathrm{~A}$ & $0.14 / 0.002 \mathrm{~B}^{+-}$ \\
& Forager & $0.99 / 0.006 \mathrm{~B}$ & $0.13 / 0.001 \mathrm{~B}^{-}$ \\
\multirow{2}{*}{ Queens } & Egg-layer & $1.06 / 0.006 \mathrm{~B}$ & $0.15 / 0.001 \mathrm{~B}^{+}$ \\
& Newly-emerged & $2.45 / 0.007 \mathrm{C}$ & $0.27 / 0.001 \mathrm{C}$ \\
\hline
\end{tabular}

Measurements followed by the same letter and signal do not differ by the Tukey-test $(\mathrm{P} 0.05)$. CV $=$ Coefficient of Variation, $\mathrm{mm}=$ millimeters, $\mathrm{N}=$ number of individuals utilized. Abdalla \& Cruz-Landim 2001a - Modified.

the secretion. This morphological cellular aspect is found in all exocrine gland that produce pheromones and in the Dufour gland of other species (Fig. 1 C, D).

Through the morphological analyses we also noticed that the worker and queen glandular cells are able to uptake substances from the hemolymph, not only in A. mellifera, but in other species of bees, these substances may be hemolymph digested circling fatty acids (Barrows et al. 1996; Abdalla et al. 1999a,b; Abdalla \& Cruz-Landim 2002,2001b,c, 2004a,b, 2005; Abdalla 2002), which will be used to build the hydrocarbons and esters (Katzav-Gozansky et al. 1997). The cells present many folds of the basal plasma membrane associated with elongated mitochondria. This basal labyrinth is a very well defined structure and the number and depth vary according to the gland activity and ovary development of the bee (Fig. 2 A-D). The meaning of the basal plasma membrane invaginations is to increase the absorption surface of uptake substances, but the meaning of so positioned, abundant, elongated mitochondria is unknown, since the fatty acids would pass through the plasma membrane by simple diffusion. One hypothesis of the mitochondria presence is that the fatty acids adsorption process by the gland may be made in a certain moment by an active expending energy process, because the lipid droplets usually are not stored in vesicles, what may saturate the cell cytoplasm with fatty acids in relationship to the external medium. In this way, when the fatty acid cellular demand is very high, the uptake of fatty acids may be made by an active energy expending transport, because the cytoplasm may be saturated (Abdalla \& CruzLandim 2002). A contrary system is used by the gut epithelial cells to uptake the lipid content into the intestinal lumen, the cells coat the lipids in micro-vesicles for the cytoplasm never be saturated in relationship with the external medium, being all lipid contained in the intestinal lumen absorbed by passive diffusion.

The expending energy to absorb lipids may explain why in A. mellifera the mitochondria of worker glandular cells are not stained by the zinc iodide-osmium tetroxide (ZIO), demonstrating that the mitochondria of workers may be inactive (Fig. $1 \mathrm{~A}$ ), since the ZIO is an staining for smooth endoplasmic reticulum and other organelles, as mitochondria, and present great affinity to the -SH groups of intercellular membranes.

The gland cells also present apical plasma membrane folds to increase the secretion discharge surface (Abdalla 2002). If the gland became inactive all this apical and basal structures are despoiling, appearing in these cell regions many vacuoles and/or myelin bodies (Fig. 3 A-F).

We also have been observed between the gland and the muscle fibers, which partially surround the gland, lipids droplets. In A. mellifera as in other species of bees (Abdalla et al. 1999a,b; Abdalla \& Cruz-Landim 2001b, 2004b, 2005) this is an additional evidence of the gland lipid uptake capacity (Fig. 4A-C).

Table II. The length and diameter of Dufour gland of Bombus terrestris workers and queens. The worker glands were analyzed according their ovary development stage (Duchateau \& Velthuis, 1989).

\begin{tabular}{|c|c|c|c|}
\hline Caste & Individuals & Length (mm) Means/CV & Diameter (mm) Means/SD \\
\hline \multirow[t]{7}{*}{ Workers } & Newly-emerged $(\mathrm{N}=10)$ & $3.30 / 0.44 \mathrm{~A}$ & $0.26 / 0.07 \mathrm{~A}$ \\
\hline & Ovary in stage $0(\mathrm{~N}=10)$ & $3.21 / 0.71 \mathrm{~A}$ & $0.26 / 0.06 \mathrm{~A}$ \\
\hline & Ovary in stage $\mathrm{I}(\mathrm{N}=12)$ & $3.03 / 0.95 \mathrm{~A}$ & $0.26 / 0.10 \mathrm{~A}$ \\
\hline & Ovary in stage II $(\mathrm{N}=10)$ & $3.6 / 0.52 \mathrm{~A}$ & $0.33 / 0.09 \mathrm{AB}$ \\
\hline & Ovary in stage III $(\mathrm{N}=12)$ & $3.25 / 0.88 \mathrm{~A}$ & $0.31 / 0.07 \mathrm{AB}$ \\
\hline & Ovary in stage IV $(\mathrm{N}=22)$ & $3.60 / 0.83 \mathrm{~A}$ & $0.40 / 0.11 \mathrm{~B}$ \\
\hline & Egg-layer $(\mathrm{N}=12)$ & $3.60 / 0.59 \mathrm{~A}$ & $0.47 / 0.03 \mathrm{~B}$ \\
\hline \multirow[t]{5}{*}{ Queens } & Newly-emerged $(\mathrm{N}=10)$ & $6.45 / 1.10 \mathrm{C}$ & $0.50 / 0.10 \mathrm{C}$ \\
\hline & Six Day Old $(\mathrm{N}=10)$ & $6.60 / 0.80 \mathrm{C}$ & $0.80 / 0.10 \mathrm{C}$ \\
\hline & End of Hibernation $(\mathrm{N}=12)$ & $6.00 / 1.00 \mathrm{C}$ & $0.60 / 0.20 \mathrm{CD}$ \\
\hline & First Brood $(\mathrm{N}=5)$ & $9.45 / 2.30 \mathrm{D}$ & $0.80 / 0.20 \mathrm{DE}$ \\
\hline & After the Competition Point $(\mathrm{N}=10)$ & $9.30 / 2.30 \mathrm{D}$ & $0.90 / 0.20 \mathrm{E}$ \\
\hline
\end{tabular}

Measurements followed by the same letter and signal do not differ by the Tukey-test $(\mathrm{P} 0.05)$. SD $=$ Coefficient of Variation, $\mathrm{mm}=$ millimeters, $\mathrm{N}=$ number of individuals utilized. Abdalla et al. 1999a,b - Modified. 

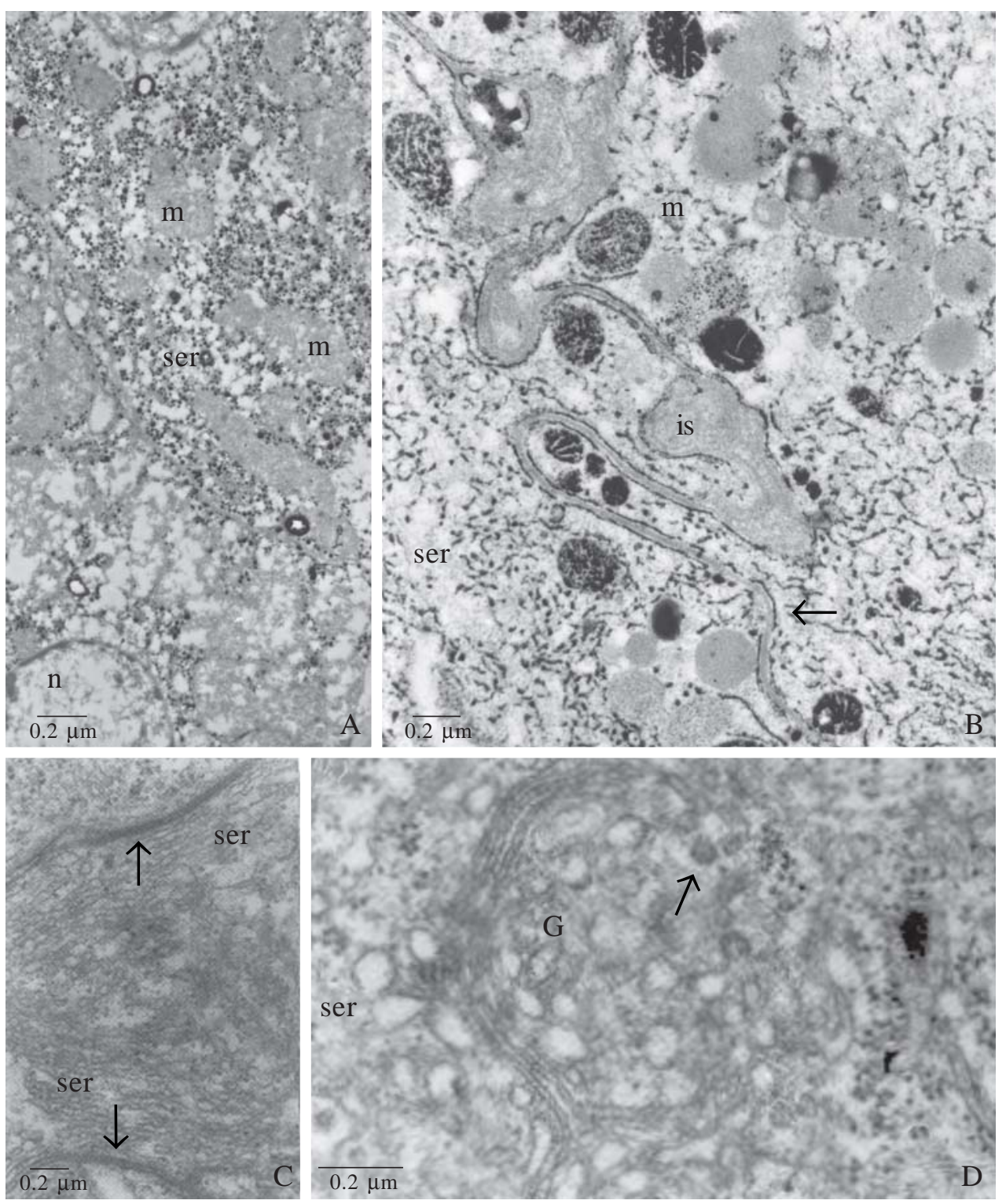

Fig. 1. A and B, transmission electron micrographs (TEM) of A. mellifera Dufour glands treated with zinc iodide-osmium tetroxide (ZIO). A. Detail of a forager worker Dufour gland epithelium, showing the non stained mitochondria $(\mathrm{m})$ and the poorly developed vesicular smooth endoplasmic reticulum (ser) $\mathrm{n}=$ nucleus. B. Detail of virgin queen cell portions between intercellular spaces (is). Notice the well-developed network of tubular smooth endoplasmic reticulum (ser), which lines all the cell contours (arrow) and stain variation of mitochondria (m). C and D, TEM of virgin queen Dufour gland cells of M. bicolor. C. Longitudinal section of a cell portion, showing smooth endoplasmic reticulum (ser) surrounding the glandular cell (arrows). Abdalla \& Cruz-Landim 2004a,b - Modified. D. Portion of the cytoplasm where it is observed an active (arrow) Golgi (G), flat smooth endoplasmic reticulum (ser) and polyribosomes(r).

In queens of Scaptotrigona postica Latreille 1807, the uptake substances seem do not cross the glandular cells, conversely they seem to bypass through the intercellular space, being released directly into the subcuticular space (Abdalla \& Cruz-Landim 2005). In A. mellifera this does not occur, as showed by the lanthanum nitrate technique in the apical region there are many occlusion septated junctions that function as a barrier against molecule transit from the intercellular space to the gland lumen (Abdalla \& Cruz-Landim 2004a). This does not occurs in S. postica.

In S. postica, the basal membrane that involves the whole gland is very developed and may actuate as a selective barrier- like of substances playing a homologue role of the occlusion septated junctions saw in A. mellifera (Fig. 5 A-D). The basal membrane property of molecule selection is also recognized in other species of insects (Ashhurst 1968; Houk et al. 1980).

In $S$. postica the basal labyrinth is very poorly developed (Fig. 5 C, D), what may be an additional evidence of such kind of uptake exogenous substances, e. g., part of the secretion could be composed of substances uptake directly from the hemolymph.

In the queen gland cells the occurrence of polymorphic mitochondria is very common (Abdalla 2002). In S. postica, specially, these mitochondria are directly evolved in lipid 

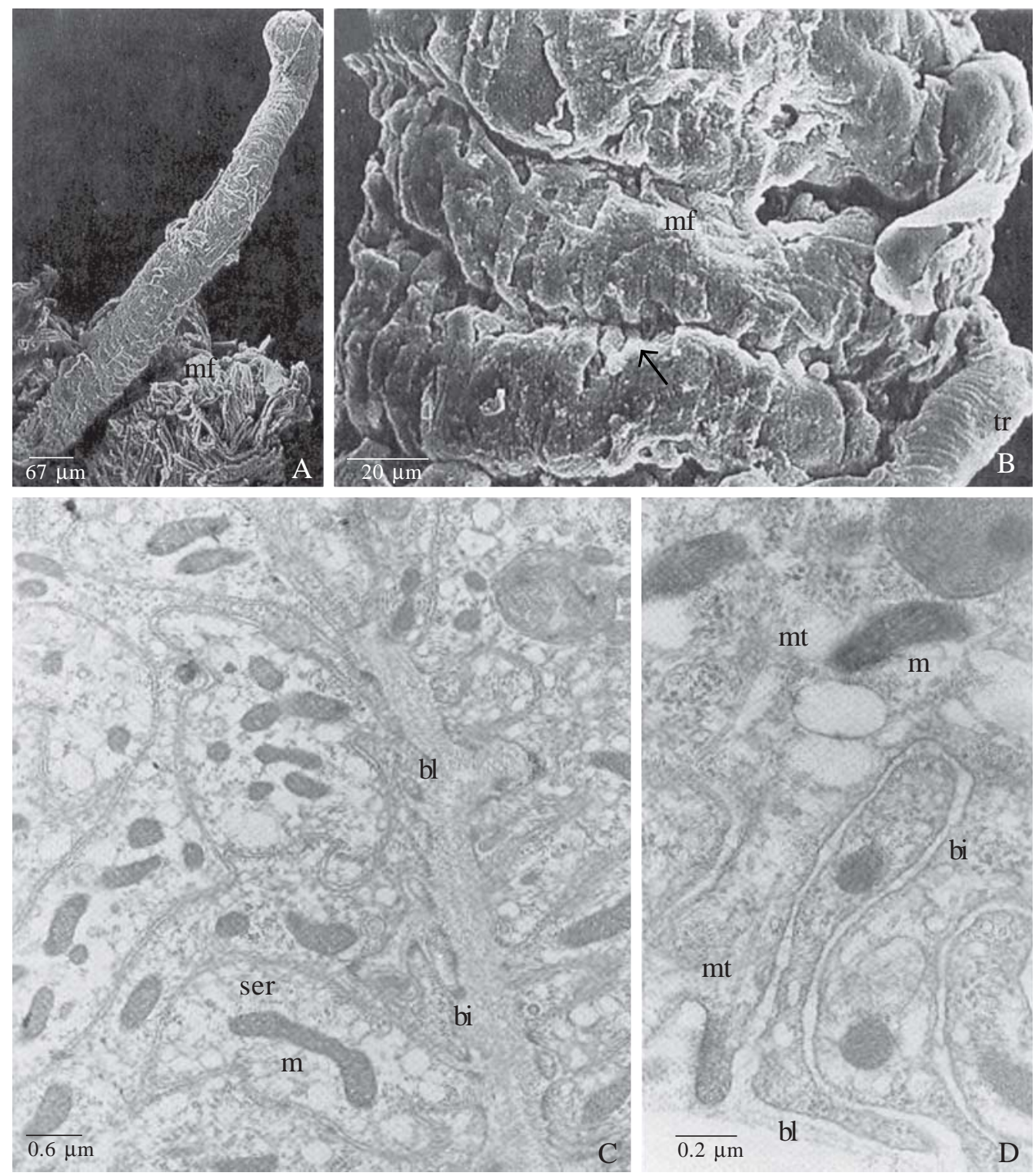

Fig. 2. A and B, scanning electron micrographs (SEM) of a virgin queen Dufour gland of A. mellifera. A. Dufour gland tubular shape. Notice the muscle fibers (mf) in the distal portion. B. SEM of the outer surface of the gland. Note the epithelial folds (arrow) and tracheoles (tr). C and D, TEM of the basal portion of Dufour gland cells of M. bicolor. C. Detail of a fold of the glandular epithelium, where numerous basal plasma membrane invaginations (bi) are observed. Notice that the epithelial fold is filled by an electron-transparent basal lamina (bl). $\mathrm{m}=\mathrm{mitochondria}$, smooth endoplasmic reticulum (ser). D. Detail of loop-like basal plasma membrane invagination (bi). Notice that the invagination attaches on the basal lamina (bl) through focal contact. The apical invaginations are supported by microtubule $(\mathrm{mt})$. $\mathrm{m}=$ mitochondria. Abdalla $\&$ CruzLandim 2004a,b - Modified.

synthesis, presenting many stages of development until reach an aspect of a secretion vesicle like, whose interior or matrix became full of morphologically recognizable material as lipid (Fig. 5 C). This phenomenon is also found in other species of bees and groups of insects, as ants (Caetano et al. 2002).

\section{The gland chemical pathway control and its relationship} with the evolutionary approach to enhance the sociability. We do not know how the ester pathways are controlled, but the queen presence is a strong factor to inhibit the ester production in young workers (Katzav-Gozansky et al. 2004). On the other hand, forager workers might synthesize esters since they are kept farer from the queen than nurse ones, but this does not occur (Katzav-Gozansky et al. 2003, 04).

Katzav-Gozansky et al. $(2003,04)$ had drawn a possible chemical pathway for the Dufour gland secretion in A. mellifera. According to these authors the esters are formed by elongation of fatty acids to very long chain acyl groups that are then modified to yield final products. The esters would proceed through the reduction to alcohols, which are subsequently esterefied by some fatty Acyl-CoAs. This is in accordance with recent data of Martin \& Jones (2004), which have found that the alcohol eicosenol in A. mellifera workers are only present in non egg-layers queens. In contrast, both egg-layer 

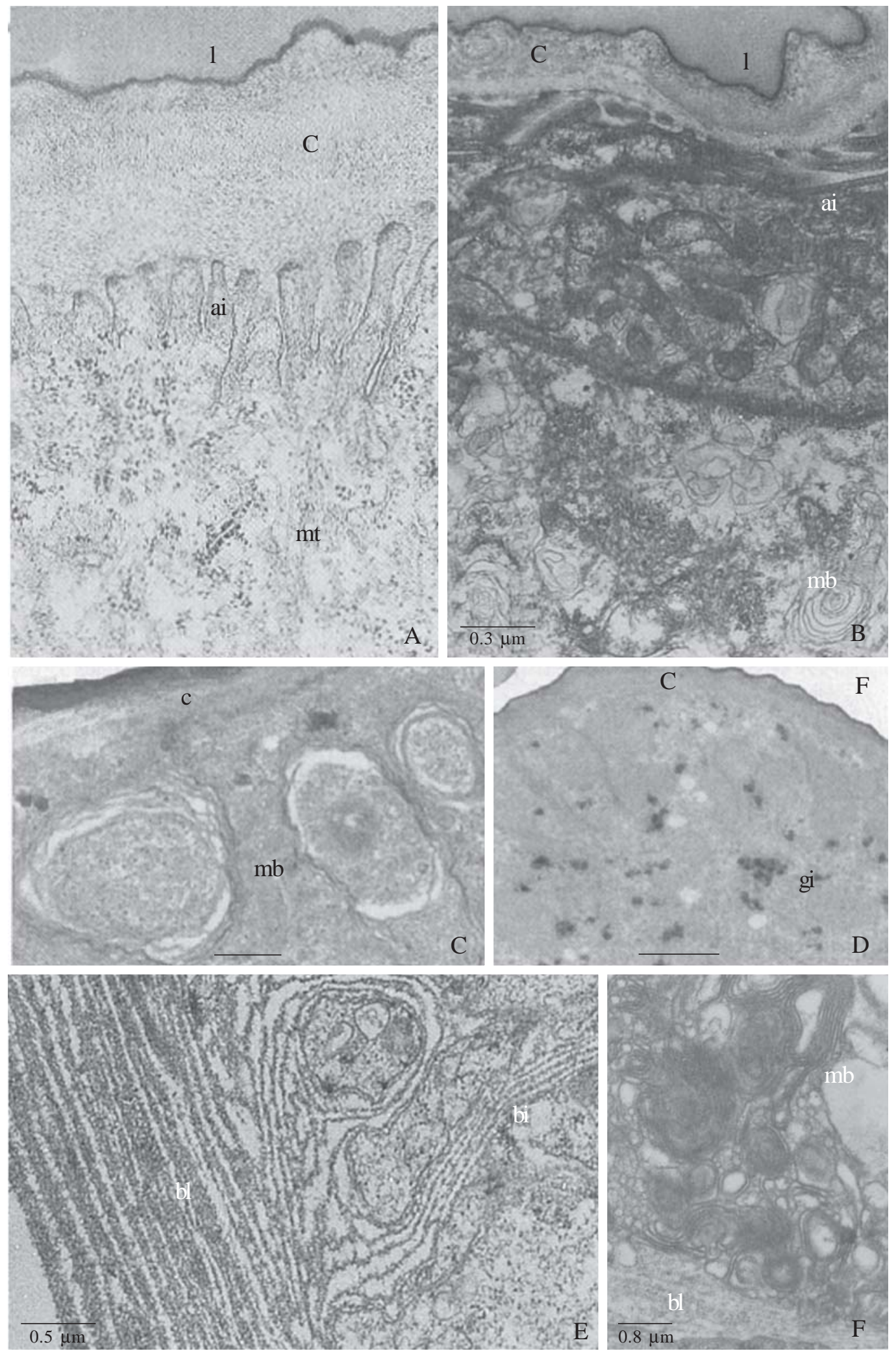

Fig. 3. A, B, E and F, TEM of Dufour gland of A. mellifera. A. Newly emerged queen gland cell apical portion, showing the plasma membrane invaginations (ai) attached to the cuticle $(\mathbf{c})$ through focal contacts. $1=1$ lumen, $\mathrm{mt}=$ microtubule. B. 29 day old virgin queen, showing disorganization of the ai, which detach from the $\mathbf{c}$ and organize in myelin bodies $(\mathbf{m b})$. C. The same $\mathbf{m b}$ formed from the disorganization of the ai may be observed in the glandular cells of $B$. terrestris queens. D In the same specie of Figure C right after hibernation it is observed some glycogen granules (gi). In Figure E it is observed the myelin bodies formation (29 day old virgin queen), being the basal lamina (bl) electrontransparent and the basal plasma membrane invagination (bi) rolling up till reaches the conformation seen in the Figure $\mathrm{F}$ (the same queen age), as typical myelin bodies (mb). bl = basal lamina. Abdalla \& Cruz-Landim 2001a; Abdalla et al. 1999a - Modified. 

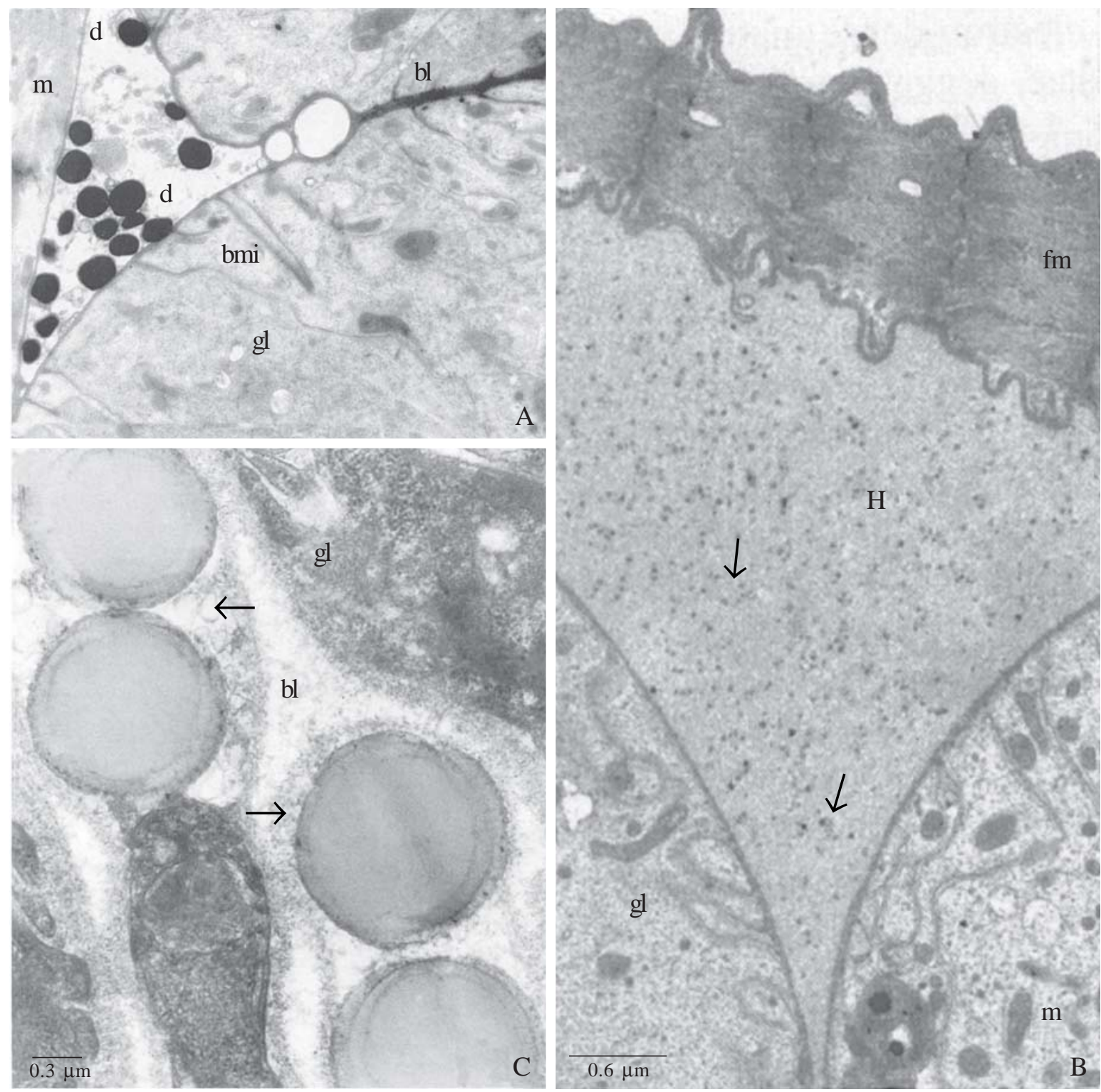

Fig. 4. A and B. Dufour glands of B. terrestris. A. Worker high active gland cells, showing outer droplets (d), between the gland cell (gl) and the muscle fiber $(\mathrm{m})$, with the same electrondensity of basal lamina (bl). bi $=$ basal plasma membrane invagination. $\mathrm{m}=$ mitochondria. $\mathrm{B}$. 6 day old virgin queen, showing amorphous material from the hemolymph $(\mathrm{H})$, containing little dots (arrows) accumulated between the gland $(\mathrm{gl})$ and the muscle fibers (fm). C. Dufour gland of M. bicolor, showing lipid droplets (large arrow) in the basal portion associated with the basal lamina (bl). Electron-transparent small vesicles are also observed out of the glandular cell (gl) associated with basal lamina (bl). Abdalla et al. 1999a,b; Abdalla \& Cruz-Landim 2004b - Modified.

anarchistic workers and all parasitic Cape workers from queenright colonies present esters and eicosenol absence, while egg-layer wild-type and anarchistic workers in queenless colonies, showed an intermediated pattern, producing both esters and eicosenol at intermediated levels. We may conclude that the eicosenol is an intermediated substance of the ester synthetic pathway of the Dufour gland secretion. If the queen is present, this pathway is break down, making workers produce only the precursors of the esters, the eicosenol, but in worker favorable conditions (queenless colonies) the ester synthetic pathway may go on and produce esters from the alcohols precursors.
Through a series of bioassays Abdalla \& Cruz-Landim (2001a) noticed that the worker Dufour gland secretion functions like a repellent for nestmate worker. Conversely, the queen secretion attracts the workers. Katazav-Gozansky et al. (2003) have also confirmed the "attractiveness function" of the queen gland secretion. Through bioassays, these authors noticed that the secretion is able to elicit worker court behavioral, being attributed this property to the esters. The repellent effect of the forager worker Dufour gland may attributed by the eicosenol and hydrocarbons found in their secretion, as already suggested by other authors (Abdalla \& Cruz-Landim 2001a; Martin \& Jones 2004). 

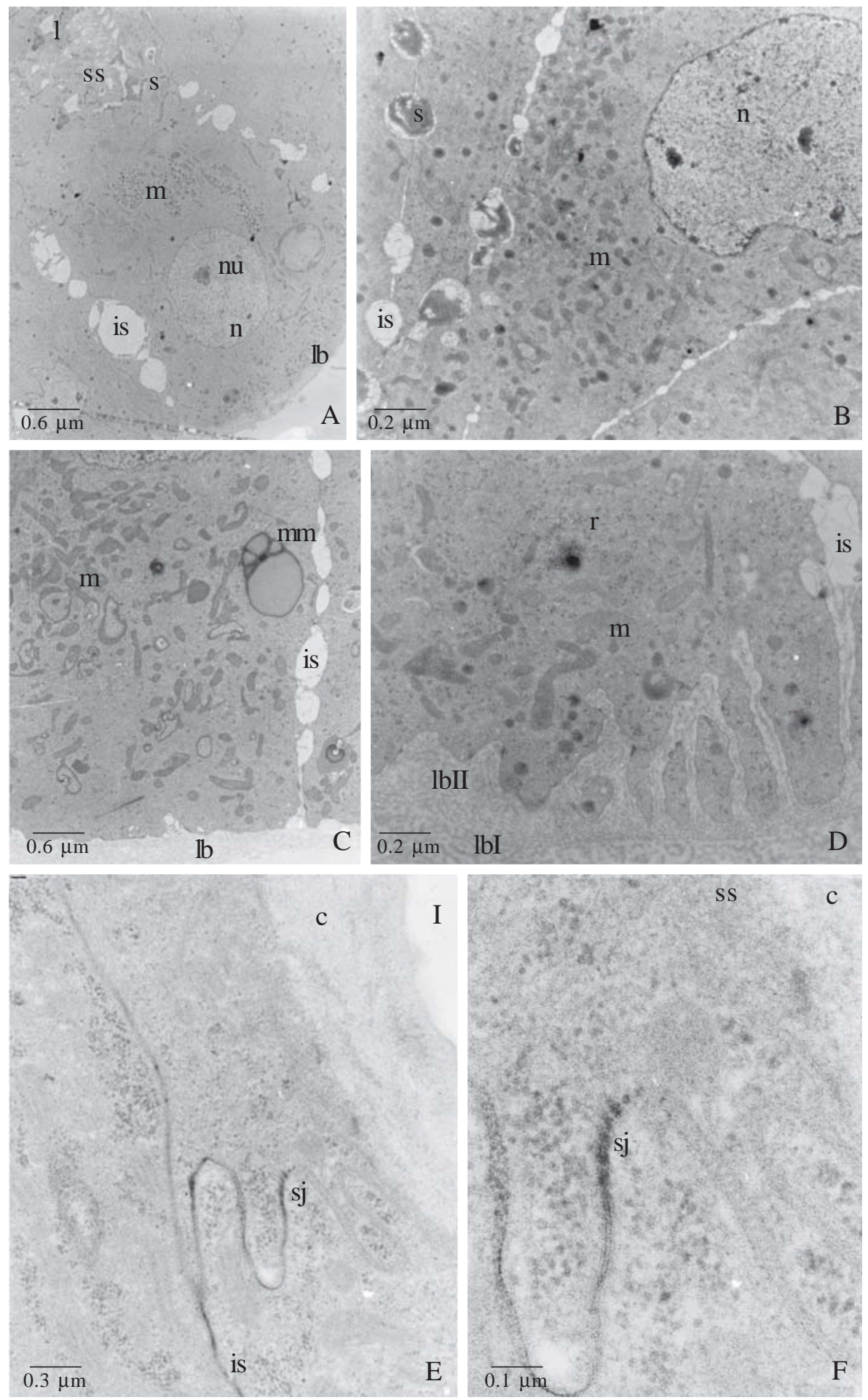

Fig. 5. A - D, S. postica virgin queen Dufour glands. A. Detail of the gland epithelium, showing enlarged intercellular spaces (is) and the subcuticular spaces (ss) filled with electrondense secretion ( $\mathrm{s}$ ). $\mathrm{lb}=$ basal lamina, $\mathrm{n}=$ nucleus, $\mathrm{nu}=$ nucleoli. $\mathrm{B}$. Detail of a glandular cell, where it is noticed the same enlargement of the intercellular spaces (is) filled with secretion (s) that present the same electrondensity of the subcuticular secretion seen in $\mathrm{A} . \mathrm{m}=$ mitochondria, $\mathrm{n}=$ nucleus. $\mathrm{C}$. Basal portion of the gland, where we may observe modified mitochondria $(\mathrm{mm})$ and many others $(\mathrm{m})$ randomly spread in the cytoplasm. Notice the well developed basal lamina (bl) and the enlarged intercellular space (is). D. Detail of the basal portion, showing the high developed basal lamina composed by two layers (bl I and bl II). Notice the poorly developed plasma membrane invagination, mitochondria (m), polyribosomes (r) and enlarged intercellular space (is). E and F. TEM of virgin queen Dufour gland of A. mellifera impregnated with lanthanum nitrate. E. Detail of the apical portion, showing the lanthanum nitrate impregnation in the intercellular spaces (is), but being barred by the septated junction (sj). F. Detail of the E. c = cuticle, sj = septated junction, ss $=$ subcuticular space. Abdalla \& Cruz-Landim 2004a; 2005 - Modified. 
Table III. Occurrence of the Dufour gland in workers of 25 species of meliponines (Kerr \& Lello 1962; Abdalla 2002 - Modified).

\begin{tabular}{|c|c|c|}
\hline Worker Ovary Development* & Species & $\mathrm{DG}$ \\
\hline $\begin{array}{l}\text { Species whose workers develop the ovaries and lay trophic } \\
\text { eggs all year long. }\end{array}$ & $\begin{array}{c}\text { Cephalotrigona capitata } \\
\text { Lestrimelita limao } \\
\text { Melipona bicolor } \\
\text { Melipona quadrifasciata } \\
\text { Melipona rufiventris } \\
\text { Meliponula boncadei } \\
\text { Nanotrigona testaceicornis } \\
\text { Oxitrigona tataira } \\
\text { Partamona cupira helleri } \\
\text { Plebeia droryana } \\
\text { Scaptotrigona bipunctata } \\
\text { Scaptotrigona postica } \\
\text { Scaptotrigona xantothrica } \\
\text { Tetragonisca angustula } \\
\text { Tetragonisca fulviventris guianae } \\
\text { Trigona spinipes }\end{array}$ & $\begin{array}{l}\text { A } \\
\text { A } \\
\text { A } \\
\text { V } \\
\text { V } \\
\text { P } \\
\text { P } \\
\text { V } \\
\text { A } \\
\text { P } \\
\text { A } \\
\text { A } \\
\text { A } \\
\text { V } \\
\text { A } \\
\text { V }\end{array}$ \\
\hline $\begin{array}{l}\text { Species whose workers never develop the ovaries, even under } \\
\text { orphanage. }\end{array}$ & $\begin{array}{c}\text { Frieseomellita freiremaiai } \\
\text { Frieseomellita languida } \\
\text { Frieseomellita varia }\end{array}$ & $\begin{array}{l}\mathrm{P} \\
\mathrm{P} \\
\mathrm{P}\end{array}$ \\
\hline $\begin{array}{l}\text { Species whose workers develop ovaries under special } \\
\text { conditions (high population or/and orphanage) }\end{array}$ & $\begin{array}{l}\text { Friesella schrottyki } \\
\quad \text { Trigona cilipes }\end{array}$ & $\begin{array}{l}\mathrm{P} \\
\mathrm{A}\end{array}$ \\
\hline $\begin{array}{l}\text { Species without information about the worker ovary } \\
\text { development }\end{array}$ & $\begin{array}{c}\text { Micheneria marginata } \\
\text { Dactylurina staudingeri } \\
\text { Trigona hyalinata } \\
\text { Trigona amalthea }\end{array}$ & $\begin{array}{l}\mathrm{V} \\
\mathrm{P} \\
\mathrm{A} \\
\mathrm{A}\end{array}$ \\
\hline
\end{tabular}

*Zuchi, personal communication. $\mathrm{A}=$ absent, $\mathrm{DG}=$ Dufour gland, $\mathrm{P}=$ Present, $\mathrm{V}=$ Vestigial.

In this way, the original function of the Dufour gland in bees has been much adapted through the bee phylogeny. In most solitary bees this gland produces a hydrophobic line to protect the developing immature, since the nests are made in soil cavities (Hefetz 1987). In social bees, the gland secretion is also used to nest entrance marking and food source marking (Hefetz 1987), in these bees the hydrophobic line was changed for an everlasting colony, in which the immature grow up in alveoli, usually made by wax.

Based on the more recent data about this gland in the highest social species, like A. mellifera and some meliponines, we may suggest three hypothetic functions for the Dufour gland:

1. The gland may give the "queen status", since the queen secretion is different than that produced by the workers (Katazav-Gozansky et al.1997) and responsible by the attraction of this caste (Abdalla \& Cruz-Landim 2001a).

2. The gland may help the identification of the "queen physiological condition", if virgin or fecundated (KatazavGozansky et al. 2003, Abdalla et al. 2004; Martin \& Jones 2004), and in the case of the meliponines may also indicate the queen productive condition, if inactive, high or low (Abdalla et al. 2004).

3. The gland may act together with the mandibular glands (Katzav-Gozansky et al. 2004), providing a reinforcement of the queen dominance under the workers, since Dufour gland extracts and queens without mandibles attract workers for court. The mandibular glands inhibit the worker ovary development and also could break down the worker esters pathway.

Besides this two groups of bees are positioned in so far distinctive phylogenetic groups. The type of secretions, as its mechanism of production seems be very similar between them.

Acknowlegements. I thank for Professor Carminda da Cruz Landim that has been intensively participated in all author' studies cited in the present investigation and for FAPESP, which gave financial support for the development of this review and for almost all author' studies.

\section{REFERENCES}

Abdalla, F. C. 2002. Glândula de Dufour, p. 127-149. In: Cruz-Landim, C. \& F. C. Abdalla (eds.). Glândulas exócrinas das abelhas, FUNPEC-RP, Ribeirão Preto, 181 p.

Abdalla, F. C. \& C. Cruz-Landim. 2001a. Behavioral responses evoked in honey bee workers by Dufour gland extracts (Hymenoptera: Apidae). Sociobiology 37: 673-678.

Abdalla, F. C. \& C. Cruz-Landim. 2001b. Changes in the morphology of the Dufour gland of Apis mellifera L. (Hymenoptera, Apidae) during the life stages of the female castes. Revista Brasileira de Entomologia 45: 123-129.

Abdalla, F. C. \& C. Cruz-Landim. 2001c. Dufour gland in the Hymenoptera (Apidae, Formicidae, Vespidae): a review. Revista Brasileira de Biologia 61: 95-106.

Abdalla, F. C. \& C. Cruz-Landim. 2001d. Size differences in the Dufour gland of Apis mellifera (Hymenoptera, Apidae) between and within the female castes. Revista Brasileira de Zoologia 18: 119-123.

Abdalla, F. C. \& C. Cruz-Landim. 2002. Mudanças morfo-funcionais e 
dinâmica do ciclo secretor da glândula de Dufour das abelhas eussociais (Apis mellifera, Bombus terrestris, Melipona bicolor): Um exemplo da plasticidade das células glandulares dos insetos, p. 45-49. In: Bauer, M. E. \& E. A. Jecke-Neto (eds.). Avanços em biologia celular, EDIPUC-RS, Porto Alegre, $231 \mathrm{p}$.

Abdalla, F. C. \& C. Cruz-Landim. 2004a. A comparative cytochemical study of the Dufour gland in the eusocial bees Apis mellifera Linné, 1758 and Melipona bicolor Lepeletier, 1836. Acta Histochemica et Cytochemica 37: 65-71.

Abdalla, F. C. \& C. Cruz-Landim. 2004b. Occurrence, morphology and ultrastructure of the Dufour gland in Melipona bicolor Lepeletier, 1836 (Hymenoptera, Meliponini). Revista Brasileira de Entomologia 48: 1-19.

Abdalla, F. C. \& Cruz-Landim, C. 2005. Ocorrência, morfologia e ultra-estrutura da glândula de Dufour de Scaptotrigona postica Latreille (Hymenoptera, Meliponini). Neotropical Entomology 34: $47-57$.

Abdalla, F. C.; G. R. Jones; E. D. Morgan \& C. Cruz-Landim. 2004. Chemical composition of the Dufour gland secretion in queens of Melipona bicolor (Hymenoptera, Meliponini). Journal of the Brazilian Chemical Society 15: 621-625.

Abdalla, F. C.; H. W. W. Velthuis; C. Cruz-Landim \& M. J. Duchateau. 1999a. Changes in the morphology and ultrastructure of the Dufour's gland during the life cycle of the bumble bee queen, Bombus terrestris L. (Hymenoptera: Bombini). Netherlands Journal of Zoology 49: 251-261.

Abdalla, F. C.; H. H. W. Velthuis; M. J. Duchateau \& C. Cruz-Landim. 1999b. Secretory cycle of the Dufour's gland in workers of bumble bee Bombus terrestris (Hymenoptera: Bombini). Netherlands Journal of Zoology 49: 139-156.

Abdalla, F. C.; L. F. Gracioli; C. Cruz-Landim \& R. L. M. Silva de Moraes. 2001. Effect of topical application of juvenile hormone $(\mathrm{JH})$ in honeybee worker larvae on the development of Dufour's and Koschewnikow's glands. Sociobiology 37: 185-191.

Ashhurst, D. E. 1968. The connective tissues of insects. Annual Review of Entomology 13: 45-74.

Barrows, E. M.; G. B. Chapman; J. E. Zenel \& A. S. Blake. 1986. Ultrastructure of Dufour's glands in active and inactive horn-faced bees, Osmia cornifrons (Hymenoptera: Megachilidae). Journal of the Kansas Entomological Society 59: 480-493.

Billen, J. P. J. 1987. New structural aspects of the Dufour's gland and venom gland in social insects. Naturwissenschaften 74: 340341.

Caetano, F. H.; F. J. Zara \& E. A. Gregório. 2002. The origin of lipid droplets in the post-pharyngeal gland of Dinoponera australis (Formicidae: Ponerinae). Cytologia 67: 301-308.

Cruz-Lopéz, L.; E. F. L. R. A. Patricio \& E. D. Morgan. 2001. Secretions of stingless bees: the Dufour gland of Nannotrigona testaceicornis. Journal of Chemical Entomology 27: 69-80.

Hamilton, W. D. 1964. The genetical evolution of social behaviour, Parts I and II. Journal of Theoretical Biology 7: 1-16, 17-52.

Hefetz, A. 1987. The role of Dufour's gland secretion in bees. Physiological Entomology. 12: 243-253.

Houk, E. J.; R. E. Chiles \& J. L. Hardy. 1980. Unique midgut basal lamina in the mosquito Aedes dorsalis (Meigen) (Insecta: Diptera).
International Journal of Insect Morphology and Embryology 9: $161-164$

Katzav-Gozansky, T.; V. Soroker; A. Hefetz; M. Cojocaru; D. H. Erdmann \& W. Francke. 1997. Plasticity of caste-specific Dufour's gland secretion in the honey bee (Apis mellifera L.) Naturwissenschaften 84: $238-241$.

Katzav-Gozansky, T.; V. Soroker \& A. Hefetz. 2000. Plasticity in caste-related exocrine secretion biosynthesis in the honey bee (Apis mellifera). Journal of Insect Physiology 46: 993-998.

Katzav-Gozansky, T.; V. Soroker; F. Ibarra; W. Francke \& A. Hefetz. 2001. Dufour gland secretion of the queen honeybee (Apis mellifera): an egg discriminator pheromone or a queens signal? Behavioral Ecology and Sociobiology 51: 76-86.

Katzav-Gozansky, T.; V. Soroker; W. Francke \& A. Hefetz. 2003. Honeybee egg-laying workers mimic a queen signal. Insectes Sociaux 50: 20-23.

Katzav-Gozansky, T.; R. Boulay; V. Soroker \& A. Hefetz. 2004. Queensignal modulation of worker pheromonal composition in honeybees Proceedings of The Royal Society of London B 271: 20652069.

Kerr, W. E. \& E. de Lello. 1962. Sting glands in stingless bees-a vestigial character (Hymenoptera, Apidae). Journal of the New York Entomological Society 70: 190-214.

Lane, N. J.; R. Dallai; P. Burighel \& G. B. Martinucci. 1986. Tight and gap junctions in the intestinal tract of tunicates (Urochordata): a freeze-fracture study. Journal of Cell Science 84: 1-17.

de Lello, E. 1971. Adnexal glands of the sting apparatus in bees: Anatomy and histology. V. (Hymenoptera: Apidae). Journal of Kansas Entomological Society 49: 85-99.

Martin, S. J. \& G. R. Jones. 2004. Conservation of bio synthetic pheromone pathways in honeybees Apis. Naturwissenschaften 91: $232-236$

Morgan, E. D. \& L. J. Wadhams. 1972. Gas chromatography of volatile compounds in small samples of biological materials. Journal of Chromatographic Science 10: 528-529.

Patrício, K. \& C. Cruz-Landim. 2003. Apis mellifera (Hymenoptera, Apini) ovary development in queens and workers from queenrigh and queenless colonies. Sociobiology 42: 771-779.

Patricio, E. F. L. R. A.; L. Cruz-López \& E. D. Morgan. 2004. Electroantennography in the study of two stingless bee species (Hymenoptera: Meliponini). Brazilian Journal of Biology 64 827-831.

Patricio, E. F. L. R. A.; L. Cruz-López; R. Maile \& E. D. Morgan. 2003. Secretions of stingless bees: the Dufour glands of some Friesomelitta species (Apidae, Meliponine). Apidologie 34: 359 365.

Ratnieks, F. L. W. 1995. Evidence for a queen-produced egg-marking pheromone and its use in worker policing in the honey bee. Journal of Apicultural Research 34: 31-37.

Reinecke, M. \& C. Walther. 1978. Aspects of turnover and biogenesis of synaptic vesicles at locust neuromuscular junctions as revealed by zinc iodide-osmium tetroxide (ZIO) reacting with intra-vesicular SH-groups. Journal of Cell Biology 78: 839-855.

Visscher, P. K. 1996. Reproductive conflict in honeybee: a stalemate of worker egg-laying and policing. Behavioral Ecology and Sociobiology 39: 237-244.

Received 24/02/2005; accepted 04/08/2005 